\title{
Association of TNF- $\alpha$ G308A gene polymorphism in essential hypertensive patients without type 2 diabetes mellitus
}

\author{
N. Ghodsian', M. Akhlaghiं ${ }^{3}$, V. Ramachandran², F. Heidari', P. Haghvirdizadeh', \\ S.A. Eshkoor ${ }^{2}$, A. Etemad ${ }^{1}$, J.A. Jamaluddin ${ }^{4}$ and P. Ismail ${ }^{1}$ \\ ${ }^{1}$ Genetic Research Group, Department of Biomedical Science, \\ Faculty of Medicine and Health Sciences, University Putra Malaysia, \\ Serdang, Selangor, Malaysia \\ ${ }^{2}$ Institute of Gerontology, University Putra Malaysia, Serdang, Selangor, Malaysia \\ ${ }^{3}$ Department of Language Science, Payam-e-Nur University, Tehran, Varamin, Iran \\ ${ }^{4}$ Department of Pediatric, Faculty of Medicine and Health Sciences, \\ University Putra Malaysia, Serdang, Selangor, Malaysia \\ Corresponding author: P. Ismail \\ E-mail: patimahismail@gmail.com
}

Genet. Mol. Res. 14 (4): 18974-18979 (2015)

Received August 17, 2015

Accepted October 18, 2015

Published December 29, 2015

DOI http://dx.doi.org/10.4238/2015.December.29.4

ABSTRACT. This study aims to investigate the effects of tumor necrosis factor alpha (TNF- $\alpha$ ) G308A gene polymorphism on essential hypertension (EHT) with or without type 2 diabetes mellitus (T2DM). The project was conducted on buccal epithelial and blood cells for case and control patients, respectively. Epithelial cells were obtained from the inner part of the cheeks. Techniques including DNA extraction, polymerase chain reaction (PCR), and restriction fragment length polymorphism (RFLP) were utilized to assess biomarkers of DNA damage. Our results demonstrated significant differences between wild and mutated genotypes among EHT patients without T2DM. We also found a significant association between wild and mutated allele frequencies in EHT patients $(P<0.05)$. Clinical characteristics between the groups (EHT with or without T2DM and 
controls) showed statistically significant association $(P<0.05)$. Overall, we show that G308A polymorphism of the TNF- $\alpha$ gene may be a significant genetic risk factor for EHT without T2DM patients in Malaysia.

Key words: Association; TNF- $\alpha$; G308A; Essential hypertension; Polymerase chain reaction; Restriction fragment length polymorphism

\section{INTRODUCTION}

Essential hypertension is a common disorder affected by environmental and polygenic factors. In order to determine the pathogenesis of hypertension and to device a novel treatment method, it is essential to find new genes associated with hypertension. In addition to heredity and immunology, cardiovascular factors can be highly relevant to the pathogenesis of hypertension (Won et al., 2011). Like inflammation, hypertension and diabetes play significant roles on the development of cardiovascular disorders (Mathieu et al., 2009). Considering the complex interplay between a range of biological and environmental factors as well as genetic susceptibility, the cause of hypertension in diabetes can be complicated. In addition, systolic blood pressure (SBP) in diabetic subjects is associated with more than two-fold increase in cardiovascular death rates (Stamler et al., 1993). According to Malaysian Hypertension Rate Mortality (MHRM), approximately one billion people suffer from essential hypertension (EHT) across the globe. Current EHT death rate is about $32.6 \%$ (5.8 million) in adults above 18 years of age, and $12.8 \%$ of the population are known to suffer from hypertension in Malaysia. In the Malaysian population, 15.2\% (2.6 million) have type 2 diabetes (T2DM), although half of this number has not yet been diagnosed (National Health and Morbidity Survey 2011). Elevated blood pressure is two-fold in subjects with diabetes and elderly subjects with type 2 diabetes compared to younger people.

Mononuclear phagocyte cells secrete tumor necrosis factor-alpha (TNF- $\alpha$ ), which is a known inflammation promoter. Vasoactive substances discharged by TNF- $\alpha$ affects endothelial cells through paracrine or autocrine signaling, which results in vasorelaxation or vasoconstriction, and regulation of blood pressure (BP) (Kahaleh and Fan, 1996). Located in short arm of the 6th chromosome (6p21.3), TNF- $\alpha$ gene polymorphism contributes to strokes as well as metabolic syndromes, infectious diseases, and hyperuricemia (Yee et al., 2000; Li, 2012). As illustrated by Bogdanski et al. (2003), serum TNF- $\alpha$ levels are considerably elevated in EHT patients compared to normotensive subjects, and continues to rise with EHT disease progression.

Hence, the present study aims to determine the relationship between EHT with or without T2DM and TNF- $\alpha$ G308A gene polymorphism.

\section{MATERIAL AND METHODS}

\section{Study sample}

Approval was received from the ethics committee of Medicine and Health Sciences Faculty for this study with the reference number UPM.FPSK.PADS/T7-MJETIKAPer/F01 JSB-Mac. Buccal mucosa epithelial cells samples were collected from 163 hypertensive subjects with or without T2DM. Blood samples were also collected from 157 control patients who have not been diagnosed with these diseases. Participants were interviewed in person regarding their health 
status, family history of disease, smoking habits, alcohol consumption, and other aspects related to the study. Case patients were divided into 2 groups: EHT and EHT + T2DM. Using a cytology brush, cells were collected by brushing the inner parts of the cheek. Swabbed cells were collected in micro-centrifuge tubes containing $300 \mu \mathrm{L}$ cell lysis buffer. Polymerase chain reaction (PCR) and Restriction fragment length polymorphism (RFLP) were used to detect SNP mutations on buccal cells (G308A polymorphism of the TNF- $\alpha$ gene). Genomic DNA extraction was extracted from buccal cells via the QIAamp DNA Blood Mini Kit (Qiagen). The isolated DNA was run on 2-3\% agarose gels, and quantified with a Nano-Drop 1000 spectrophotometer (Thermo Scientific, USA).

TNF- $\alpha$ gene polymorphisms were specified via the mutagenically separated PCR method. Briefly, genomic DNA was extracted via the Mini Qiagene Kit. Each PCR reaction was assembled as follows: $0.3 \mu \mathrm{L}$ each primer, $6 \mu \mathrm{L}$ ImmoMix master mix (Bioline), and 17.4 $\mu \mathrm{L}$ sterile water. The PCR cycling parameters are as follows: $94^{\circ} \mathrm{C}$ for $5 \mathrm{~min} ; 35$ cycles at $95^{\circ} \mathrm{C}$ for $60 \mathrm{~s}, 57^{\circ} \mathrm{C}$ for $60 \mathrm{~s}$, and $72^{\circ} \mathrm{C}$ for $90 \mathrm{~s}$. The melting temperature range was selected from $72^{\circ} \mathrm{C}$ to $95^{\circ} \mathrm{C}$. All samples were stored at $4^{\circ} \mathrm{C}$ for later use. A no DNA template was included in each run as a negative control. PCR products (147 bp) were separated using Nco1 restriction enzymes, and visualized on a $2 \%$ agarose gel by UV light. DNA ladders (Bioline) were used to verify the sizes of the products in RFLP.

\section{Statistical analysis}

Statistical analysis in the present study was conducted by SPSS version 21. Two-tailed Student $t$ - tests and one way ANOVA tests were used to compare all variables among the groups (P $<0.05$ was determined to be significant statistically). Genotype distributions with Hardy-Weinberg expectations were calculated using chi-squared tests, and allelic frequencies were analyzed by the gene-counting method. In order to detect the effect of high risk alleles, Odds ratios (OR) with 95\% confidence intervals $(\mathrm{Cl})$ were also checked.

\section{RESULTS}

In this study, 330 individuals were approached; 10 volunteers were unfortunately excluded due to extreme values and inconsistent results. Subjects were recruited from the Seremban Hospital in Malaysia, and were subdivided into three groups following administration of a health screens: 75 EHT patients (group 1), 88 EHT + T2DM (group 2), and 157 control subjects (group 3). In Table 1, the clinical characteristics of the subjects are displayed.

\begin{tabular}{|c|c|c|c|c|c|c|}
\hline Parameter & Group $1(\mathrm{~N}=75)$ & Group $2(\mathrm{~N}=88)$ & Group $3(N=157)$ & $\begin{array}{l}\text { Group } 1 \text { vs } \\
\text { Group } 2\end{array}$ & $\begin{array}{c}\text { Group } 1 \text { vs } \\
\text { Group } 3\end{array}$ & $\begin{array}{c}\text { Group } 2 \text { vs } \\
\text { Group } 3\end{array}$ \\
\hline Age (year) & $59.45 \pm 10.34$ & $59.05 \pm 11.10$ & $52.51 \pm 9.41$ & .654 & .000 & .000 \\
\hline $\mathrm{SBP}(\mathrm{mmHg})$ & $152.01 \pm 23.10$ & $150.51 \pm 20.00$ & $122.21 \pm 11.24$ & .625 & .000 & .000 \\
\hline $\mathrm{DBP}(\mathrm{mmHg})$ & $94.12 \pm 10.00$ & $93.00 \pm 9.34$ & $76.20 \pm 9.00$ & .245 & .000 & .000 \\
\hline BMI chol (mmol/l) & $26.21 \pm 6.02$ & $28.04 \pm 4.25$ & $25.00 \pm 4.00$ & .020 & .024 & .000 \\
\hline FBS chol (mmol/l) & $5.46 \pm 1.11$ & $7.89 \pm 1.35$ & $5.04 \pm .50$ & .000 & .000 & .000 \\
\hline T-chol $(\mathrm{mmol} / \mathrm{l})$ & $5.02 \pm 1.10$ & $4.53 \pm 1.04$ & $5.10 \pm 1.31$ & .033 & .818 & .023 \\
\hline LDL-chol (mmol/l) & $3.01 \pm 1.10$ & $3.00 \pm 1.00$ & $3.21 \pm 1.10$ & .201 & .006 & .000 \\
\hline HDL-chol (mmol/l) & $1.34 \pm .34$ & $1.21 \pm .30$ & $1.30 \pm .52$ & .045 & .309 & .196 \\
\hline TG (mmol/l) & $1.50 \pm .52$ & $2.00 \pm .53$ & $1.23 \pm .55$ & .260 & .000 & .000 \\
\hline
\end{tabular}

One way-ANOVA P < 0.05 was achieved between Group 1 - EHT, Group 2 - EHT + T2DM, and Group 3-Control subjects. Variables are presented as mean \pm SD. 
Significant differences were observed between group 1 and 2 in body mass index (BMI), fasting blood sugar (FBS), total cholesterol (TCH), and high density lipoprotein (HDL) levels ( $\mathrm{P}<$ 0.05). However, age, systolic blood pressure (SBP), diastolic blood pressure (DBP), low-density lipoprotein (LDL), and triglyceride (TG) were similar. On the other hand, there were significant differences in all parameters between group 1 and 3 excluding TCH and HDL; HDL was only parameter that did not show significant differences between groups 2 and 3 .

\section{Genotyping and allele frequency}

G308A polymorphism of the TNF- $\alpha$ gene was amplified by PCR, followed by RFLP using the restriction enzyme Nco I. The amplicon was $147 \mathrm{bp}$ in size. RFLP products of the TNF- $\alpha$ gene were excised into 147, 126, and 21 bp fragments. The GG genotype considered the wild type group, while the GA and AA genotypes were the heterozygote and mutated groups, respectively. The genotype distributions of TNF- $\alpha$ G308A polymorphism in each group are illustrated in Table 2. Homozygous GG genotype showed the highest frequency of the three groups, Mutant genotype had no record for group 3. Significant differences were identified in genotypes and allele frequencies between group 1 and $3(P<0.05)$, but not between group 2 and $3(P>0.05)$.

\begin{tabular}{|c|c|c|c|c|c|c|c|}
\hline & & \multicolumn{3}{|c|}{ Individuals } & \multicolumn{3}{|c|}{$P$ value } \\
\hline & & $\begin{array}{l}\text { Group 1 } \\
(\mathrm{N}=75)\end{array}$ & $\begin{array}{l}\text { Group 2 } \\
(\mathrm{N}=88)\end{array}$ & $\begin{array}{c}\text { Group } 3 \\
(\mathrm{~N}=157)\end{array}$ & $\begin{array}{c}\text { Group } 1 \text { vs } \\
\text { Group } 2\end{array}$ & $\begin{array}{c}\text { Group } 1 \text { vs } \\
\text { Group } 3\end{array}$ & $\begin{array}{c}\text { Group } 2 \text { vs } \\
\text { Group } 3\end{array}$ \\
\hline \multirow[t]{3}{*}{ Genotype } & GG & 60 & 73 & 142 & & & \\
\hline & GA & 14 & 14 & 15 & & & \\
\hline & AA & 1 & 1 & 0 & & & \\
\hline$P$ value & & & & & .588 & .024 & .080 \\
\hline \multirow{2}{*}{ Allele frequency } & $G$ & 74 & 160 & 299 & & & \\
\hline & $A$ & 16 & 16 & 15 & & & \\
\hline$P$ value & & & & & 0.710 & 0.031 & 0.089 \\
\hline Odds ratio & & & & & 0.838 & 0.448 & 0.535 \\
\hline Confidence interval & & & & & $0.40-1.73$ & $0.21-0.92$ & $0.26-1.09$ \\
\hline
\end{tabular}

\section{DISCUSSION}

The present study is perhaps the first of its kind examine genotype and allele frequencies of TNF- $\alpha$ G308A gene polymorphism in essential hypertension without T2DM in Malaysian subjects. A strong relation between EHT and TNFa gene G308A polymorphism was found in the current study. The A allele of the TNFa G308A gene is probably the predisposed gene for EHT. Being one of the deadliest and life-threatening diseases, EHT morbidity rate is increasing each year. EHT is considered a genetic heterogeneity disorder, contributing $30-50 \%$ to the variation in BP (Newhouse et al., 2005). Aside from factors such as genetics, diet, and psychology, mechanisms of EHT is also significantly impacted by inflammation (Amer et al., 2011). Inflammation influences EHT through adhesion molecules such as interleukin- 6 and inflammatory factor such as TNF- $\alpha$ (Bogdański et al., 2003). Increases in TNF- $\alpha$ transcription, serum TNF- $\alpha$ level, and A allele of the TNF- $\alpha$ G308A gene enhance EHT susceptibility, as confirmed by the current analysis. This allele is also related to insulin resistance, T2DM, obesity, body fluid C reactive protein and arteria coronary (Li, 2012). 
Several recent studies have further confirmed the correlation between $T N F-\alpha$ and blood pressure. As shown by Ito et al. (2001) in Japanese females, TNF- $\alpha$ may modulate LDL cholesterol and blood pressure. Moreover, we also found significant differences in LDL between patient and healthy groups. Krikovszky et al. (2002) researches showed that the TNF-alpha-308A allele carrier state seemed to be related to low SBP and DBP values in diabetic youngsters. Yoo et al. (2007) reported that TNF- $\alpha-308 G$ allele vector is related with elevated EHT hazard in Koreans. Some studies carried out by Peng et al. (2011) also illustrated a strong relation between the TNF- $\alpha-308 \mathrm{~A}$ allele and EHT. Similar results were also verified by Sookoian et al. (2005). According to Bogdanski et al. (2003), serum TNFa- level in EHT subjects was higher as compared to normotensive individuals, and was enhanced during the progression of EHT. Similar results in mice were also confirmed by Mazor et al. (2010). These findings are still preliminary; studies on EHT and TNF-a G308A gene polymorphism is still limited (Sheu et al., 2001; Sookoian et al., 2005).

According to widespread evidences, high expression of TNF- $\alpha$ in adipose tissue is associated with insulin resistance, which is a significant pathogenic mechanism in T2DM development (Ouyang, 2006). Some candidate-gene researches on diabetes in the Han Chinese population have been lately conducted, and the relationships between TNF- $\alpha-308 G>A$ and T2DM have drawn close attention. Studies indicate that there is no statistically significant relationship between TNF- $\alpha-308 \mathrm{G}>A$ polymorphism and T2DM risk in Malaysian. However, TNF- $\alpha-308 G$ $>A$ is a significant risk factor for T2DM in the country. These findings were contrary to a previous study (Wu et al., 2010). Feng et al. (2011) examining various ethnic populations (divided into Asian, European and others) showed that $T N F-\alpha-308 G>A$ gene polymorphism was not related with T2DM risk in these categories. Considering the wide genetic diversity that exist in this gene between difference ethnic backgrounds, it is strongly recommended to perform a systematic examination on the relation of TNF- $\alpha-308 G>A$ with T2DM before implementing the genetic outcomes into clinical practice. In summary, our results highlight the association of G308A polymorphism in the TNF- $\alpha$ gene in Malaysian hypertensive subjects without type 2 diabetes. The A allele of the G308A polymorphism of TNF- $\alpha$ gene is suggested to be an important genetic marker for essential EHT but not in EHT with T2DM Malaysian subjects.

\section{Conflicts of interest}

The authors declare no conflicts of interest.

\section{ACKNOWLEDMENTS}

We fully acknowledge the cooperation of the volunteers and all participants who generate their generous support from Universiti Putra Malaysia.

\section{REFERENCES}

Amer MS, Elawam AE, Khater MS, Omar OH, et al. (2011). Association of high-sensitivity C-reactive protein with carotid artery intima-media thickness in hypertensive older adults. J. Am. Soc. Hypertens. 5: 395-400.

Bogdański P, Kujawska-Łuczak M, Łacki J and Pupek-Musialik D (2003). Evaluation of selected interleukins, tumor necrosis factor, insulin and leptin in obese patients with hypertension. Pol. Merkur. Lekarski. 15: 347-349; discussion 9-51.

Feng RN, Zhao C, Sun CH and Li Y (2011). Meta-analysis of TNF 308 G/A polymorphism and type 2 diabetes mellitus. PLoS One 6: e18480. 
Ito $\mathrm{H}$, Ohshima A, Tsuzuki M, Ohto N, et al. (2001). Association of serum tumor necrosis factor- $\alpha$ with Serum low-density lipoprotein-cholesterol and blood pressure in apparently healthy Japanese women. Clin. Exp. Pharmacol. Physiol. 28: 188-192.

Kahaleh M and Fan P (1996). Effect of cytokines on the production of endothelin by endothelial cells. Clin. Exp. Rheumatol. 15: 163-167.

Krikovszky D, Vásárhelyi B, Tóth-Heyn P, Körner A, et al. (2002). Association between G- 308A polymorphism of the tumor necrosis factor- $\alpha$ gene and 24-hour ambulatory blood pressure values in type 1 diabetic adolescents. Clin. Genet. 62: 474-477.

Li YY (2012). Tumor necrosis factor-alpha G308a gene polymorphism and essential hypertension: a meta-analysis involving 2244 participants. PLoS One 7: e35408.

LiWei G, HongYan W and YanMei H (2009). Correlation between tumor necrosis factor $\alpha$ and $\beta$ gene polymorphisms and essential hypertension. J. Xinxiang Med. Coll. 26: 352-354.

Mathieu P, Poirier P, Pibarot P, Lemieux I, et al. (2009). Visceral obesity the link among inflammation, hypertension, and cardiovascular disease. Hypertension 53: 577-584.

Mazor R, Itzhaki O, Sela S, Yagil Y, et al. (2010). Tumor necrosis factor- $\alpha$ A possible priming agent for the polymorphonuclear leukocyte-reduced nicotinamide-adenine dinucleotide phosphate oxidase in hypertension. Hypertension 55: 353-362.

Newhouse SJ, Wallace C, Dobson R, Mein C, et al. (2005). Haplotypes of the WNK1 gene associate with blood pressure variation in a severely hypertensive population from the British Genetics of Hypertension study. Hum. Mol. Genet. 14: $1805-1814$.

Ouyang-YW (2006). Recent progress on relationship between adipose cell cytokine and insulin resistance. Med. Recapitulate 4: 016.

Peng CY, Zhou CL and He QZ (2011). Association of TNF- $\alpha$ gene -308G/A polymorphism with essential hypertension in Han racial origin in Hunan. Chin. J. Clin. Pharmacol. Ther. 16: 57-60.

Sheu WH, Lee WJ, Lin LY, Chang RL, et al. (2001). Tumor necrosis factor alpha -238 and-308 polymorphisms do not associate with insulin resistance in hypertensive subjects. Metabolism 50: 1447-1451.

Sookoian S, Garcii SI, Gianotti TF, Dieuzeide G, et al. (2005). The G-308A promoter variant of the tumor necrosis factor-alpha gene is associated with hypertension in adolescents harboring the metabolic syndrome. Am. J. Hypertens. 18: 1271-1275.

Stamler J, Vaccaro O, Neaton JD and Wentworth D (1993). Diabetes, other risk factors, and 12-yr cardiovascular mortality for men screened in the Multiple Risk Factor Intervention Trial. Diabetes care 16: 434-44.

Won JH, Ehret G, Chakravarti A and Olshen RA (2011). SNPs and other features as they predispose to complex disease: genome-wide predictive analysis of a quantitative phenotype for hypertension. PLoS One 6: e27891.

Wu N, Zhou L-L, Guo D, Wang Y, et al. (2010). Association of the promoter polymorphism of tumor necrosis factor alpha $308 \mathrm{G} / \mathrm{A}$ gene with the type 2 diabetes mellitus: a Meta-analysis. Chin. J. Pract. Internal Med. 30: 927-929.

Yee L, Tang J, Herrera J, Kaslow RA, et al. (2000). Tumor necrosis factor gene polymorphisms in patients with cirrhosis from chronic hepatitis $\mathrm{C}$ virus infection. Genes Immun. 1: 386.

Yoo CS, Hwang WJ, Hong SH, Lee HJ, et al. (2007). Relationship between iris constitution analysis and TNF-alpha gene polymorphism in hypertensives. Am. J. Chin. Med. 35: 621-629. 